\title{
IMPROVING THE BENEFITS OF KARAMBA INTO TOURISM ACTIVITIES: AN EFFORT TO REDUCE THE ECOLOGICAL IMPACT OF AQUACULTURE IN MANINJAU LAKE, INDONESIA
}

\author{
Firdaus FIRDAUS * \\ STKIP PGRI Sumatera Barat, Department of Sociology Education, \\ Padang Utara-25173, Indonesia, e-mail: firdaus@stkip-pgri-sumbar.ac.id \\ Nurus SHALIHIN \\ UIN Imam Bonjol Padang, Faculty of Ushuluddin and Religious Study, \\ Department of Religions, Kuranji-25153, e-mail: nurus_djamra@yahoo.com
}

\section{Dian Kurnia ANGGRETA}

STKIP PGRI Sumatera Barat, Department of Sociology Education, Padang Utara-25173, Indonesia, e-mail: anggreta14@gmail.com

\section{Faishal YASIN}

STKIP PGRI Sumatera Barat, Department of Sociology Education, Padang Utara-25173, Indonesia, e-mail: faishalyasin@gmail.com

\section{Rio TUTRI}

STKIP PGRI Sumatera Barat, Department of Sociology Education, Padang Utara-25173, Indonesia, e-mail: rio_tutri@yahoo.com

\begin{abstract}
Citation: Firdaus, F., Shalihin, S., Anggreta, D.K., Yasin, F., \& Tutri, R. (2019). IMPROVING THE BENEFITS OF KARAMBA INTO TOURISM ACTIVITIES: AN EFFORT TO REDUCE THE ECOLOGICAL IMPACT OF AQUACULTURE IN MANINJAU LAKE, INDONESIA. GeoJournal of Tourism and Geosites, 26(3), 726-736. https://doi.org/10.30892/gtg.26304-392
\end{abstract}

\begin{abstract}
The aim of this study is to explore the potential extending of floating net cage (known as karamba in local term) benefits as tourism attractions. By extending the benefit of karamba as a tourism attraction, the impact of aquaqulture to lake ecology and quality of water can be reduced. In the last decade, tourism has evolved into sustainable tourism activity by making nature and culture as primary object. Therefore, tourism is also trusted can be overcome the ecological problems of Maninjau lake that caused by karamba aquaqulture. The research was conducted in nagari around the Maninjau lake area during 2016-2017. Data wer collected through semi-structured interviews and focus group discussions. The results indicate that karamba has the potential to be developed as a tourism activity through the participation of karamba practitioners as tourism operators. However, the type of participation cannot be entirely spontaneous type, but induced participation type is also needed to develop the karamba tourism. Several strategies and challenges in developing karamba tourism are identified.
\end{abstract}

Key words: karamba tourism, sustainable tourism, participation

\footnotetext{
* Corresponding author
} 


\section{INTRODUCTION}

The area of Lake Maninjau is a valley beneath the group of hills around the lake which in folklore is the remnant of Mount Tinjau eruption. This lake is listed as the eleventh largest lake in Indonesia as well as the second largest lake in West Sumatera (Firdaus, 2018). The lake is called Maninjau having an area of $129,69 \mathrm{~km}^{2}$ (BPS Agam, 2017). Lake Maninjau has been famous for one of the tourist destinations in West Sumatera which has green view and is supported by other tourism potentials, such as kelok 44 (bend of 44). Apart from being tourist destination, Lake Maninjau is also used by local community as an area of fish aquaqulture by employing floating net cage (Keramba Jaring Apung/KJA) since 1991 (Yodi, 2017). In local term, the aquaqulture system is known as karamba (this term is used hereinafter).

Karamba in Lake Maninjau was began with a trial done by Fisheries Agency of West Sumatera in 1991 with a total of 17 plots (Yodi, 2017). Good economic value was push the fish aquaqulture grow rapidly from 12 plots in 1992 (Asnil, 2012) to 17.226 plots in 2016 (BPS Agam, 2017). In addition to economic value, the existence of karamba also affects the ecology of the lake. The ecological impact is called tubo belerang (natural upwelling) by the local society which results in death of the fish since 1997 (Saputra, 2015; Yodi, 2017). Natural upwelling causes the decrease of quality of lake water characterized by strong odor causing itch to the skin and bloom of disturbing alga, particularly Microcystis aeruginosa (Asnil, 2012; Saputra, 2015).

Phenomenon of tubo belerang has become a threat for karamba in Lake Maninjau area since the last 20 years (Asnil, 2012). Moreover, it has been an annual threat for fish farmers causing them to lose much money since the last 10 years. Besides, based on the Local Regulation number 5, 2014 concerning with Lake Maninjau Conservation Processing, the number of KJA in Maninjau has exceeded the capacity of the lake. Based on the Local Regulation, the capacity of the lake is only 6.000 plots, while the number of KJA in 2016 is 17.226 plots (BPS Agam, 2017). This condition implicates to the sedimentation of the lake which mainly causes the fish to die harming karamba farmers.

Economically, business of karamba has provided more money for community of Nagari living in Lake Maninjau. Nasution et al., (2011) states the average net profit earned by karamba in Lake Maninjau with total capital of Rp. 10.203.600 is worth Rp. 2.396 .400 (Nasution et al., 2011). Such profit is equivalent to $23,4 \%$ of the total venture capital. However, the ecological impact caused by aquaqulture activity has threatened ecology of the Lake as well as economic viability of the farmers. In addition, the damage of the environment also implicates to public health exposed by polluted lake (Nasution et al., 2011; Saputra, 2015). In response to the ecological impact affecting economy and community health, karamba begins to limit. The restriction cused the number of karamba has not increased since 2015 to 2016 (BPS Agam, 2017). However, as an important livelihood for local people, these restrictions have implications for the income of farmers. This paper offers alternative economic activities through tourism to preserve the lake while still utilizing karamba facilities as a means of tourism activities.

According to UNEP \& UNWTO (2005), tourism hold a special position to contribute in order to create sustainable development and it's challenges. The position is due to two things, first is the dynamic and growth of tourism and the contribution to the economic of many contries and local destination. Second, tourism involves consumer (visitors), the industry, the environment and local communities to the special relationship because the visitors travel to the producer and product. This leads to important and unique aspect of the relationship between tourism and sustainable development, that is interaction, awareness and dependency. 


\section{LITERATURE REVIEW \& THEORITICAL FRAMWORK}

Historically, the tourism in Indonesia is not separated from the alternative policy to deal with the limitation of natural resources. Tourism activity that has been going on since colonial era (Picard, 2005; Spillane, 1987) becomes the priority of development during the New Order era because of the decrease of oil role as a foreign exchange earner and the decline of export value in the non-oil sector. On the other hand, the potential to develop tourism is very high (Spillane, 1987; Yoety, 2008a). Indonesia's tourism development policy is stated in Law number 9, 1990 concerning with Tourism which stipulates that Indonesia's Tourism is sustainably directed through optimizing the cultural aspects. Specifically, Presidential Instruction number 9, 1969 affir ms that the development of Indonesia's tourism aims at economic, social, cultural and natural conservation interests (Firdaus \& Tutri, 2017). Development of tourism in the last decades has been shifting from mass tourism to niche tourism which means that the tendency to travel on a mass changes into trend to travel individually preferring to see objects and tour attractions of special interest as well as ecotourism (Yoety, 2006).

At the same time, the policy of national tourism development is directed to special interest tourism (Kementrian \& Pariwisata, 2015). Several alternative tourist attractions concerning with ecotourism and local activities begin to grow and develop in Indonesia (Firdaus \& Tutri, 2017). The contribution of natural tourism in Batusuhunan to socio economic and environment sustainability (Hijriati \& Mardiana, 2014), economic contribution of Sambi Tourism in the form of increasing public income and emerging new business opportunities (Sudarmadji \& Darmanto, 2014) as well as economic benefit of marine tourism development in Sikakap, Mentawai (Andriyani et al., 2012) are forms of tourism contributions for the society in Indonesia.

The ecotourism growth trend is also part of sustainable tourism development known as ecotourism. Although the concept still overlaps between conventional tourism category on one hand and alternative tourism category on the other, it is part of sustainable tourism because of its contribution towards sustainable development and sustainability (Björk, 2007). In addition, ecotourism also closely relates to pro-poor tourism and volunteer tourism (Wearing \& Neil, 2009). Therefore, tourism activity can be categorized as an environmentally friendly alternative economic activity. In expressed simply, WTO defined sustainable tourism as tourism that takes full account of its current and future economic, social and environmental impacts, addressing the needs of visitors, the industry, the environment and host communities (UNEP \& UNWTO, 2005:12).

Base on the definition, UNEP \& UNWTO (2015) state the princips of sustainability is refer the environmental, economic and socio-cultural aspects of tourism development, and a suitable balance between the three dimensions to guarantee its long-term sustainability. For this reason, the sustainable tourism should make optimal use of environmental resources that constitute a key element in tourism development, maintaining essential ecological processes and helping to conserve natural resources and biodiversity. Second, respect the socio-cultural authenticity of host communities, conserve their built and living cultural heritage and traditional values, and contribute to inter-cultural understanding and tolerance. Third, ensure viable, long-term economic operations, providing socio-economic benefits to all stakeholders that are fairly distributed, including stable employment and income-earning opportunities and social services to host communities, and contributing to poverty alleviation. Lozano-Oyola et.al., (2012:659) state that sustainable tourism is not a specific tourism, but more an approach that cen be used to make all type of tourism more environmentally, socially and economically beneficial. Thus, Word Tourism Organization define the the sustaibale tourism as meet the needs of present tourist and host regions 
while protecting and enhancing opportunitites for the future (WTO, 2001). In this manner, the connections between economic development, environmental protection and social equity, each element reinforcing the other is important aspect on tourism development (Zolfani et al., 2015). In this manner, tourism activities should be focused on resource management in which all economic, social and aesthetic requirements are fulfilled, while simultaneously respecting cultural integrity, essential ecological processes, biological diversity and life support system (Lozano-Oyola et al., 2012).

To integrate the environmental, social and economic benefits from the tourism, community engagedment is a prerequisite in tourism developmnet. Van Niekerk (2014:82) identified three schools of thought about community participation in tourism. First, considers that under the best condition, most people tend to avoid the community participation. Second, recognize that community participation is a voluntary process in which the community will only engage in destination planning and development when doing so is likely benefit them. Third, argues that the community often wants to participate in destination development but is rarely provided the opportunity to do so effectively. Therefore, the development of tourism destination should ensure the community engagement in all process of planning in where communities involved have ample opportunities to participate if they want to (Zhao \& Ritchie, 2007). According to Cevat Tosun (1999), there are three typologies of community participation on tourism development process, spontaneous, induced and coersive. Spontaneous participation is voluntary, base up without external support. Its represents an ideal mode of participation, as it mirrors a voluntary and autonomous activity on the part of people to handle their problem without government or other external agencies help. Induced participation is sponsored, mandated, and officially endorsed. It's also known as formal, top-down, passive participation or pseudo participation. Coersive participation is compulsory, manipulated, and contived. It's also known as community oppressive and narrow participation. This typology of participation will be used as an analytical framework in the development of karamba fish aquaqulture as a special interest tourism activity.

\section{METHODOLOGY}

\section{Population and Participant}

Lake Maninjau is administratively located in Tanjung Raya Sub district of Agam Regency, West Sumatera. To reach the research area, one must take around 3-4 hours drive from Minangkabau International Airport at Padang (the capital of West Sumatera Province). Selecting the right participants in Maninjau with appropriate experience and knowledge about the area and fish aquaqulture was essential for effective and efficient data collection (Gillham, 2005). Thus, we applied the purposive sampling method to select the participant, as this method able to precisely deliver the researcher to the right informant in the process of data collecting (Suri, 2011). To gain the complete information, we interviewed the local and regional government, community leaders, youths and businessmen of karamba. The particular criteria of informant were chosen to provide insight to Lake Maninjau area as a whole. The participant were chosen because their knowledge of the Lake Maninjau area, their involvement in development of area, and as actors in karamba aquaculture. Thus, they are familiar and close to Lake Maninjau development issues and activities of karamba aquaqulture and its social, economic and environmental impacts. The traditional Minangkabau language has used during interviews to encourage trust and confort from all participant base on their local knowledge and wisdom without having to force them to find equivalent words in other languages (bahasa and or English). Interview data in Minangkabau then translated into Indonesian, and then translated to English for the purposes of this publication. 


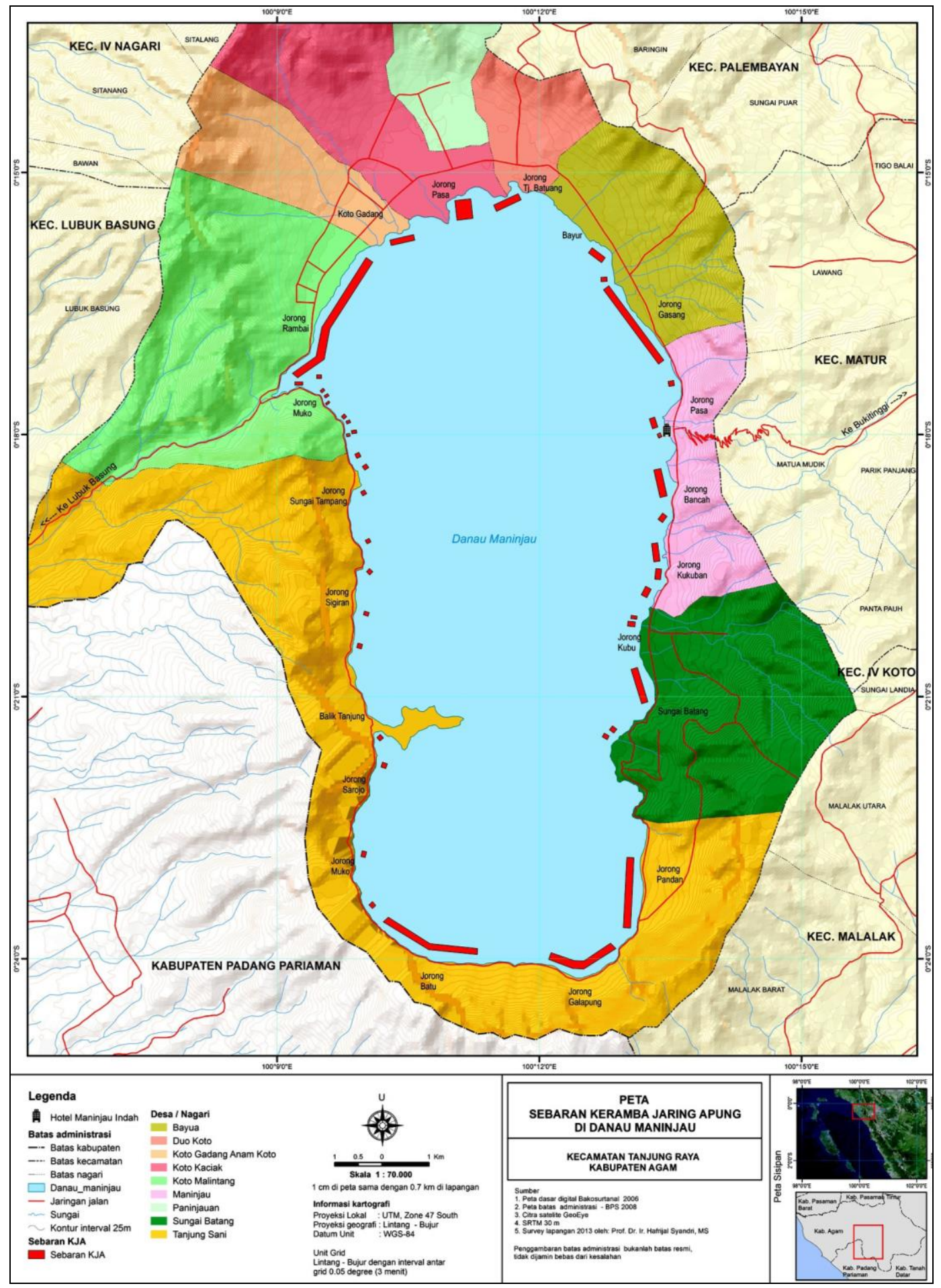

Figure 1. Map of Tanjung Raya sub-district, the of study area (Source: Syandri et al., 2014) 


\section{Data Collection Methods}

In-depth interviews and focus group discussions (FGD) were used to gain the better information for the purpose of this study. We conducted semi-structured interview (approximately 1-2 hours for each person) with 25 informant (2 government tourism office of Agam district, 2 sub-district government, 3 Walinagari (village head), 5 community leader, 5 youth and youth leaders, and 10 businessmen of karamba). Focus Group discussion (FGD) lasting for 2 hours with 12 participant (owner and worker of aquaqulture karamba) and 1 youth leader. Semistructured interview and FGD were chosen because it's provide opportunities for researchers to probe and explore the information needed by asking further questions or asking participant to explain their answers or elaborate their response (Silverman, 2013). Data collection conducted from 2016 to 2017 in Nagari around Lake of Maninjau at subdistrict of Tanjung Raya, Agam Regency, West Sumatera, Indonesia. Semi-structured interview conducted during several field visits in 2016 and 2017. Intensive visits were made at the end of 2016 and early 2017. FGD conducted in Mei 2017 in Nagari Maninjau. Most of the focus group participants is owner of karamba and obtained a high school education.

One of them has a graduate education and former of community empowerment facilitator. The entire FGD participants were young people who were active in various youth activities at the Nagari level. In addition, study document in the form of policy, activity report, research result and others became secondary data sources of this study. Observation was carried out by following the routine of fish farming activities conducted by fish farmers. The activities were then documented through photos and videos.

\section{Data Analysis}

Data analysis is done by listening to the interviews and FGDs recording, and then transcribing them in table system according to question and answer. The transcripts of interview and FGD data then processed through indetifying and grouping the information according to the themes of research topic. Then, the entire data were analyzed by using data reduction/data verification, data display and data interpretation which is then used to make conclusion (Miles \& Huberman, 1992). After that, the result of data analysis was presented in the form of narration in accordance to the need of writing.

\section{RESULTS DISCUSSIONS}

\section{Lake Of Maninjau Area and Tourism Potential}

As mentioned above, Lake Maninjau area is included in the administrative area of Tanjung Raya sub-district in Agam Regency, West Sumatera, Indonesia. The sub-district having an area of $\pm 244.03 \mathrm{Km}^{2}$ consists of nine Nagari surrounding the lake. Tanjung Raya generally has tropical weather with varying temperatures between $23^{\circ} \mathrm{C}$ to $26^{\circ} \mathrm{C}$ having an average air temperature of $24^{\circ} \mathrm{C}$. The altitude of the area is between 100-1000 masl with type $\mathrm{C}$ of climate which is located between $100^{\circ} \mathrm{O} 5-100^{\circ} 16 \mathrm{E}$ and $0^{\circ} 12-0^{\circ} 23 \mathrm{~S}$. The distance from Capital of Sub district to Capital of Regency (Lubuk Basung) is $29 \mathrm{~km}$, in which the average time to get there by using vehicle is +30 . Meanwhile, the distance to get to the capital of Province (Padang) is $143 \mathrm{~km}$ which takes +3 hours to arrive there.

Topography of the sub district consists of steep hills and valleys and is crossed by four rivers, such as Tumayo, Amparan, Kurambik which flows from the hills to Lake Maninjau, and Batang Antokan as the exit of Lake Maninjau water flow. Apart from having 4 rivers, Tanjung Raya is also surrounded by 10 hills with an average height of above 1200 masl. The hills are Silayang, Asahan, Kurambik, Gadang, Rangkiang, Ampang Sikikih, Air Singsang, Surian, Tanjung, Sikakal Dewi. In general, there are three tourism potentials in Lake Maninjau including natural potential, historical relic and cultural 
potential (Table 1). Through its potential, Lake Maninjau belongs to tourism development area of A which means it has the second largest number of tourists after Java and Bali with chief products in the form of mountainous nature and Malay culture (Tim Konsorsium, 1997). In the provincial level, Lake Maninjau is one of the priority areas of tourism development. The Tourism Development Master Plan (RIPP) of Agam Regency in 2003 decides that Lake Maninjau is the central tourism development I (WPP I).

The WPP I includes tourism activity in Tanjung Raya emphasizing on the development of natural tourism, history, art and culture consisting of 2 SKW. Tourism development in Tanjung Raya is directed at; Natural tourism, Marine tourism and Cultural \& scientific tourism (Tourism, Art and Culture Official of Agam, 2003).

Table 1. Tourist Attractions and Tourism Potentials of Lake Maninjau (Data source: Firdaus, 2018)

\begin{tabular}{|c|c|c|c|}
\hline Category & \multicolumn{2}{|c|}{ Tourist Attractions/Tourism Potentials } & Information \\
\hline \multirow{7}{*}{$\begin{array}{l}\text { Natural } \\
\text { Tourism }\end{array}$} & \multicolumn{2}{|c|}{ Lake Maninjau } & \\
\hline & \multicolumn{2}{|c|}{ Kelok 44} & Curving road which is in good condition \\
\hline & \multicolumn{2}{|c|}{ Aia tigo raso } & Managed by society \\
\hline & \multicolumn{2}{|c|}{ Cikalo waterfall } & The management is not good yet \\
\hline & \multicolumn{2}{|c|}{ Muko-muko tourist park } & Managed by society \\
\hline & \multicolumn{2}{|c|}{ Aia angek swimming pool } & Managed by society \\
\hline & \multicolumn{2}{|c|}{ Gadih rantih waterfall } & The management is not good yet \\
\hline \multirow{3}{*}{$\begin{array}{l}\text { Tours of } \\
\text { Heritage }\end{array}$} & \multicolumn{2}{|c|}{ Museum of Buya Hamka's birthplace } & Good management \\
\hline & \multicolumn{2}{|c|}{ Inyiak DR's (Buya Hamka's father) library } & Good management \\
\hline & \multicolumn{2}{|c|}{ Grave and birthplace of Inyiak DR } & Good management \\
\hline \multirow{3}{*}{$\begin{array}{l}\text { Cultural } \\
\text { Potential }\end{array}$} & Art & $\begin{array}{l}\text { Tambua tansa music } \\
\text { Talempong music } \\
\text { Traditional self-defense art } \\
\text { Traditional dance of Minangkabau } \\
\text { Debus (ritual display of invulnerability) }\end{array}$ & $\begin{array}{l}\text { Available in each village } \\
\text { especially tambua-tansa }\end{array}$ \\
\hline & $\begin{array}{l}\text { Daily } \\
\text { Activities }\end{array}$ & $\begin{array}{l}\text { Hunting pig } \\
\text { Hunting mouse } \\
\text { Wedding party } \\
\text { Fish cultivation by using KJA } \\
\end{array}$ & Available in each village \\
\hline & $\begin{array}{c}\text { Traditional } \\
\text { Activities }\end{array}$ & $\begin{array}{l}\text { Wedding ceremony } \\
\text { Mangaji tamaik ritual }\end{array}$ & Available in each village \\
\hline
\end{tabular}

\section{Potency of Karamba as Tourism Attraction in Lake Maninjau}

Karamba in Lake Maninjau area is a series of patterned activities routinely conducted by fish farmers. The patterned activities generally comprise the process of fish breeding, maintenance and harvesting. The fish breeding is the process of maintaining fish seeds by using small pore nets in karamba, where previously fish seeds were purchased from seed cultivator. The process is done when the fish age 3-5 weeks. During the process, the seeds of fish are filtered which are then transferred to medium pore net. The screening process takes place in several stages based on growth of the seeds. Maintenance is daily activities which consist of feeding fish, picking up dead fish (carcasses) and separating fish based on its size. The feeding fish is carried out every morning and evening with special food for freshwater fish cultivation for 3-4 months. The Harvesting is an activity to liftfish from karamba, in which the activity is carried out in groups consisting of lifting fish from karamba to the place of pigging, weighing fish, packing them with oxygen and bringing them to the truck carrier.

Karamba aquaqulture is done in the middle of the lake with a minimum depth of $15 \mathrm{~m}$. Hence, the majority of karamba is placed in the middle of the lake, in which to 
access the karamba, it is needed special transportation. The transportation used to get karamba is a river craft without outrigger. The daily activities to cultivate fish by using river craft as a means of transportation starts from sowing seeds of fish, bringing food for fish, feeding them until harvesting. Thus, activities of fish farmers always involve the use of the river craft. Furthermore, in karamba, the farmers provide small huts as a storage place of fish food. Besides, there is a bridge connecting one plot to another or one karamba to another, in which the bridge usually can be passed by at least 2 adults simultaneously. The series of activities in the process of fish cultivation are potential things which can be used as tourism activities, in which they can be managed into packets consisting of series of activities. Main activities in the packets are sailing by using river craft and feeding the fish. Sailing by using the river craft is an activity that is not experienced by many people, especially those living in mountains and in urban areas without beach. Thus, the activity of exclusive sailing becomes special experience for visitors.

Besides, feeding fish in the cages ( $k a r a m b a$ ) will also provide a unique experience for the visitors. Throwing fish food into the cages in the middle of the lake which is then raided by thousands of fish simultaneously becomes a relaxation for the visitors. Aside from being part of daily activities included in culture category, karamba is very close to nature. The proximity includes activities relating to natural resources. Therefore, in the context of tourism, the activities embrace cultural activities and other activities concerning with nature. Thus, karamba can be developed into cultural and natural tourism activities by packaging them into special interest tourism activities. The activities of using river craft without outrigger and feeding fish over the lake are main tour activities with the principle of sustainable tourism. Other additional activities can be developed in accordance with the need of tourists and the ability of the managers. The main principle of this activity is to prioritize natural aspects rather than imitations and to prioritize activities that tourists are invited to see and to watch nature closely, to enjoy its authenticity, to learn, to admire the beauty of nature, flora and fauna including cultural aspects (Pendit, 2006; Yoety, $2008 \mathrm{~b})$. Through the principle, tourism activities are integrated with the activity of fish cultivation done by the society. Thus, tourism activities simultaneously empower the fish farmers. The process of empowerment can be accomplished through the principle of social development, in which society becomes the main actor (Firdaus, 2016).
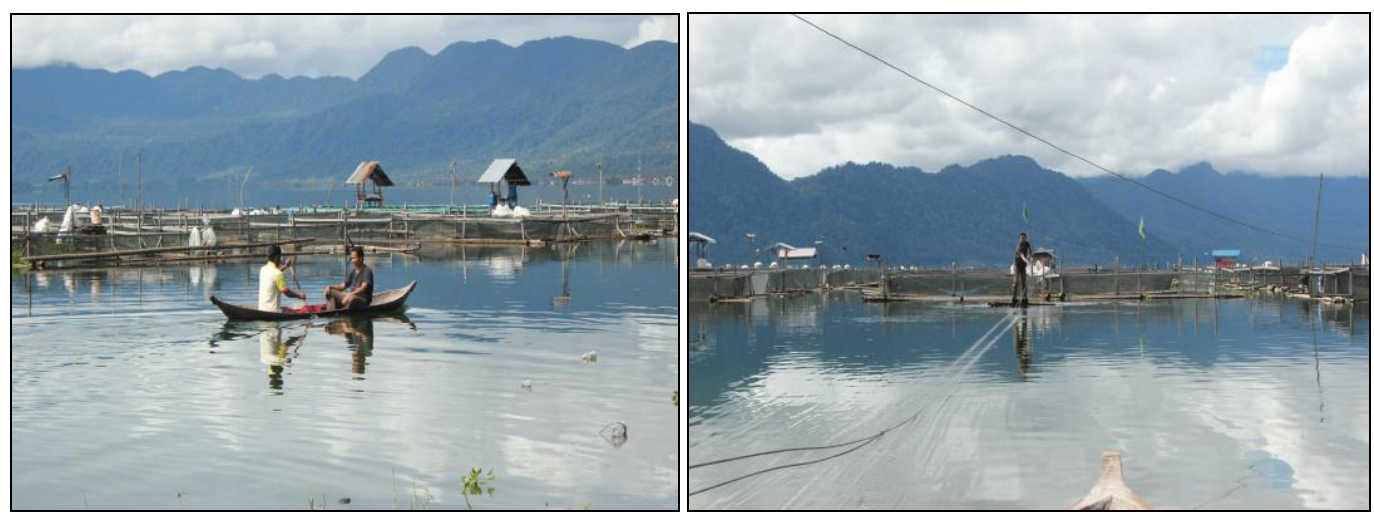

Figure 2. Picture of Some Karamba Tourism Activities (Source: Primary Data, 2017)

Karamba is part of cultural tourism potential as well as natural tourism. Culture in this case refers to the definition proposed by Edward B. Taylor which consists of knowledge, belief, art, moral, law, custom and capability and other habits as members of 
society (Saifuddin, 2005). Meanwhile, the concept of culture is a tourism that connects certain activity with places, traditions, arts, ceremonies, and experiences photographing a nation and its people with a certain identity that is different from the tourists (Hughes, 2002; McKercher, 2002). The concept of natural tourism is a tour activity used to enjoy the beauty of nature which involves the elements of education, understanding, and support to the efforts of environmental conservation and the involvement of local communities around ecotourism destination areas in its management (Arida et al., 2014).

\section{Development of Karamba Tourism; Strategies and Its Challenges}

Basically, karamba is a daily activity carried out by local communities that has the potential to be developed as a tourist attraction. This potencies is to make all aquaculture activities -from fish breeding to harvest- as a tourist attraction. These activities mainly ride the river craft from the edge of the lake to the karamba in the middle of the lake and feed the fish. However, in the local community this potential has not been made an opportunity, so no karamba tourism activities carried out until this research was conducted. Nevertheless, in the FGD activities all participants were enthusiastic to develop karamba as a tourist attraction. This enthusiasm became as the basic capital to development of karamba as tourism activity with a participatory approach through community engagement. Because the main of tourist attraction is ride the river craft and feed the fish at karamba, the development of karamba tourist attractions must involve the participation of karamba practitioners. This is to make sure that they are skilled people in cultivation activities especially in controlling river craft with loads of goods and passengers on the lake.

In addition, the requirement is applied to ensure that the activity is not merely created for the tourism interest. The type of partiscipation is spontaneous participation in according Tosun (1999), is the participation with some characteristics included bottom-up; participation in whole process of development including decision making, implementation, sharing benefit and evaluating; self planning; and wide participotion. By using these characteristics, the process of developing karamba tourism is fully handed to karamba practitioners starting from the planning, implementation, and monitoring and evaluation process. The practitioners can also develop networks widely with various stakeholders from various circles in developing karamba tourism. By using unstructured and unofficial day to day interactions between members of local communities and local leaders in spontaneous participation (Tosun, 1999), community participation can be encouraged through create a group of karamba tourism. The member of group is formed from the karamba practitioner.

Through the group, all actors of tourism activity can be controlled and they can supervise each other. Besides, through the group, activities of tourism can also be designed and members of the group can decide various rules relating to the persistence of the activities. In addition, the management and its development karamba tourism can be integrated with other tourism activities in Lake Maninjau area (Firdaus, 2018).

Although the opportunity to participate in the development of karamba tourism by practitioners is very high, there are two challenges in its development, human resources, infrastructure an safety standard. Human resource constraints are mainly related to the managerial and innovation capabilities of practitioners in developing karamba tourism. However, this can be overcome by involving universities or tourism agencies to upgrade the capabilities of practitioners in terms of management and innovation of karamba tourism. Even though it takes time, this can be done quickly through intensive training and mentoring. The second obstacle relates to infrastructure of lake. There is no dock that can be used around the lake by practitioners to tether or climb biduk before pedaling to the middle of the lake. Usually, the practitioners use a shallow edge of the lake to climb the boat and push it to the lake. Automatically, every ride on a river craft the practitioners will get wet. For practitioners, this is normally, but not for tourist purposes. For tourist service standards, a dock must be available to raise and lower tourists from river craft. 
The third is related to safety standard on ride the river craft. Usually, practitioners have not used buoys as safety on ride of river craft to go to karamba at the middle of the lake. Traditionally, they still rely on swimming skill if there is an accident.

This is does not apply to tourists who cannot be sure to have the ability to swim in the lake. Therefore, the availability of safety is a necessity.

In FGD, even though the enthusiasm for developing karamba tourism was quite high, participants considered infrastructure and security standards to be the biggest obstacle in developing karamba tourism. The challenge of the dock infrastructure, they can overcome by determining the location that can be used as a dock, but they collide with the constraints of the source of the cost to build the dock. Likewise with the security standards, they assess the cost of completing security equipment in driving river craft is quite high because they have to provide a minimum of 2 sets for every 1 river craft that should be used by them and passengers. To overcome the financial constraints in building the dock and security equipment, they hope to government to provide it, or private parties who are willing to donate. Referring to the type of participation categorized by Tosun (1999), the limitations of practitioners in finding solutions to infrastructure and security standards, constrain them to falling to induced participation. According to Tosun (1999:120), its can be solve through such strategies as motivating and training local leaders to assume leadership roles, building self-management and cooperative organizations, and supporting civic and community bodies. However, an efforts are needed to make practitioners willing to provide their funds voluntarily to overcome the infrastructure constraints they face.

\section{CONCLUSION}

The Lake Maninjau area has been facing the ecological impact of karamba since the last two decades. To overcome this ecological impact, the regional government of Agam District has issued a policy to limiting the number of karamba.

As a result, the number of karamba has not increased in the last 3 years, but the restriction has implications for the income of karamba farmers. To increase economic benefits, karamba can be used as tourist attractions, because tourism is widely proven to contribute to the social and economic benefits to local communities and at the same time maintain environmental sustainability. The use of karamba as a tourist attraction can be developed by involving karamba practitioners as tour operators by relying on drive of river craft activities and feeding fish at the karamba in the middle of lake.

The development of tourism activities can be done with the approach of spontaneous participation. However, some infrastructure constraints and safety standards in driving river craft make practitioners fall into iduced participation. Karamba tourism can be managed into certain activities in the form of packets, such as fishing, sailing by using the river craft and feeding fish above karamba.

Management and development of karamba tourism can also be integrated with existing tourism activities in the Lake Maninjau area.

\section{Aknowlegments}

This contribution results from research projects with own funds.

\section{REFERENCES}

Andriyani, I., Hardi, E., \& Husnita, L. (2012). Socio-economic Change of Local Community After Marine Tourism Development at Sikakap Island, Mentawai District. Jurnal Ilmu Sosial Mamangan, 1(2), 95-101. Arida, I. N. S., Baiquni, M., Janianton, D., \& Ahimsa-putra, H. S. (2014). The Dynamic of Tri Ning Ecotourism at Bali: The Problems and Strategic of Developmnet Three Types of Ecotourism at Bali. Kawistara, 4(2), 111-127. Asnil. (2012). Economic Assessment Analysis and Sustainable Lake Resource Utilization Policy (Case Study of Maninjau Lake, West Sumatra). Institut Pertanian Bogor. 
Björk, P. (2007). Defenition Paradoxes; From Concept to Defenition. In J. Higham (Ed.), Critical Issues in Ecotourism: Understanding a Complex Tourism Phenomenon (pp. 23-45). Elsevier Ltd.

Firdaus, F. (2016). Evaluation of the Social Development Project in the Mbeliling Forest Zone Community Group, District of Manggarai Barat, NTT. Jurnal Ilmu Sosial Mamangan, 5(1), 13-22. https://doi.org/10.22202/mamangan.1926

Firdaus, F. (2018). Potency of Integrated Cultural Tourism Development at Maninjau Lake Area, West Sumatera. Mimbar : Jurnal Sosial Dan Pembangunan, 34(1), 72-82.

Firdaus, F., \& Tutri, R. (2017). Potential for Ecotourism Development in Nagari Kotobaru, Sub-District of X Koto, Tanah Datar District, West Sumatera. Jurnal Kawistara, 7(2), 115-206. https://doi.org/10.22146/kawistara.13570.

Gillham, B. (2005). Research Interviewing: The Range of Techniques. New York: Open University Press.

Hijriati, E., \& Mardiana, R. (2014). Community Based Ecotourism Effect on Changing Ecological, Social and Economic Conditions di Batusuhunan Village, Sukabumi. Solidity: Jurnal Sosiologi Pedesaan, o2(03), 146-159.

Hughes, H. L. (2002). Culture and Tourism: A Framework for Further Analysis Culture and Tourism. Managing Leisure, 7(3), 164-175. https://doi.org/10.1080/1360671022000013701

Lozano-Oyola, M., Blancas, F. J., González, M., \& Caballero, R. (2012). Sustainable Tourism Indicators as Planning Tools in Cultural Destinations. Ecological Indicators, 18, 659-675. https://doi.org/10.1016/j.ecolind.2012.01.014.

McKercher, B. (2002). Towards a Classification of cultural tourists. International Journal of Tourism Research, 4(1), 29-38. https://doi.org/10.1002/jtr.346

Miles, M. B., \& Huberman, A. M. (1992). Qualitative Data Analysis. Jakarta.: UI Press.

Nasution, Z., Sari, Y. D., \& Huda, H. M. (2011). Aquaculture on Maninjau Lake: Anticipation of Policies for Handling the Impact of Fish Mass Death. Jurnal Kebijakan Sosial Ekonomi Kelautan Dan Perikanan, 1(1), $19-31$.

Pendit, N. S. (2006). Tourism Science; A Prime Introduction. Jakarta: Pradnya Paramita.

Picard, M. (2005). Bali: Cultural Tourism and Tourism culture. Jakarta: Gramedia.

Saifuddin, A. F. (2005). Contemporary Anthropology: A Critical Introduction to Paradigms. Jakarta: Kencana.

Saputra, A. (2015). Opportunities and Challenges of Aquaqulture in Maninjau Lake, West Sumatra Province. Media Akuakultur, 5(1), 18-21.

Silverman, D. (2013). Doing Qualitative Research (4th Editio). London: Sage Publication Ltd.

Spillane, J. J. (1987). Tourism Economics, History and Prospects. Yogyakarta: Kanisius.

Sudarmadji, \& Darmanto, D. (2014). Environmental Impact and Disaster Risk Tourism Village Development; Case Study in Sambi Tourism Village. Kawistara, 4(2), 111-224.

Suri, H. (2011). Purposeful Sampling in Qualitative Research Synthesis. Qualitative Research Journal, 11(2), 63-75. https://doi.org/10.3316/QRJ1102063

Syandri, H., Junaidi, Azrita, \& Yunus, T. (2014). State of Aquatic Resources Maninjau Lake West Sumatra Province, Indonesia. Journal of Ecology and Environmental Sciences, 5(1), 109-113.

Tim Konsorsium. (1997). Study of the Preparation of the National Tourism Development Master Plan, Phase II, 1996/1997: Final Report.

Tosun, C. (1999). Towards a Typology of Community Participation in the Tourism Development Process. Anatolia, 1O(2), 113-134. https://doi.org/10.1080/13032917.1999.9686975

Van Niekerk, M. (2014). Advocating community participation and integrated tourism development planning in local destinations: The case of South Africa. Journal of Destination Marketing and Management, 3(2), 82-84. https://doi.org/10.1016/j.jdmm.2014.02.002

Wearing, S., \& Neil, J. (2009). Ecotourism: Impacts, Potentials and Possibilities? (second). elsevier Ltd.

Yodi, W. A. (2017). Cage Fish Cultivation in Nagari Koto Gadang VI Koto, Tanjung Raya District, Agam Regency (2000-2016). University Andalas.

Yoety, O. A. (2006). Cultural Tourism: Problems and Its Solutions. Jakarta: PT. Pradnya Paramita.

Yoety, O. A. (2008a). Tourism Economy; Introduction, Information and Implementation. Jakarta: Penerbit Buku Kompas.

Yoety, O. A. (2008b). Tourism Planning and Development. Jakarta: Pradnya Paramita.

Zhao, W., \& Ritchie, J. R. B. (2007). Tourism and Poverty Alleviation: An Integrative Research Framework. Current Issues in Tourism, 1O(2-3), 119-143. https://doi.org/10.2167/cit296.o

Zolfani, S. H., Sedaghat, M., Maknoon, R., \& Zavadskas, E. K. (2015). Sustainable Tourism: A Comprehensive Literature Review on Frameworks and Applications. Economic Research-Ekonomska Istrazivanja, 28(1), 1-30. https://doi.org/10.1080/1331677X.2014.995895

*** BPS Agam. (2017). Agam in Figure 2017. Lubuk Basung: BPS Kab. Agam.Ministry of Tourism. (2015). Ministry of Tourism Performance Report 2014. Jakarta.

*** Tourism, Art \& Culture official of Agam. (2003). Compilation of the Tourism Development Master Plan (RIPP) of Agam District 2002-2012. Pemda. Kabupaten Agam.

*** UNEP \& UNWTO. (2005). Making Tourism More Sustainable - A Guide for Policy Makers.

*** WTO. (2001). The concept of Sustainable Tourism. Retrieved from http://www.worldtourism.org/sustainable/concepts.htm

Submitted:

10.04.2019
Revised:

30.08.2019
Accepted and published online

03.09.2019 